\title{
(IN) Consonância da Tutela Antecipada no CPC DE 2015 COM O ESTADO DEMOCRÁTICO DE DIREITO ${ }^{1}$
}

\author{
Edmilson Araujo Rodrigues* \\ Cynara Silde Mesquita Veloso**
}

1 Introdução: o paradigma da tutela provisória. 2 A tutela provisória de urgência antecipada. 2.1 A tipologia da tutela antecipada. 2.2 A tutela antecipada no novo código de processo civil de 2015. 3 As diferentes formas de tutela provisória. 4 A tutela antecipada e a teoria neoinstitucionalista do processo. $4.1 \mathrm{O}$ contraditório, a isonomia e a ampla defesa na democratização da tutela antecipada. 5 Conclusão. Referências.

\section{RESUMO}

Objetivou-se neste artigo analisar a tutela provisória de urgência antecipada no NCPC de 2015 com enfoque na teoria neoinstitucionalista do processo. A partir dessa matriz teórica, questiona-se: será que a tutela provisória de urgência antecipada no NCPC de 2015 está em consonância com o Estado democrático de direito? Para responder ao enigma em questão, o caminho metodológico da pesquisa será classificado quanto à forma de abordagem de qualitativa e do ponto de vista dos seus objetivos será exploratória. No que tange aos procedimentos técnicos adotados na análise, a pesquisa será definida como bibliográfica e documental, uma vez que será utilizado um referencial teórico por meio de doutrinas e da legislação pertinente. Os resultados da investigação levaram a considerar que, embora o instituto em destaque seja importante, há, pois, uma incongruência no que se refere ao acesso igualitário à justiça pensada na perspectiva dos litigantes. Assim, percebe-se a não possibilidade do contraditório e da ampla defesa para o polo passivo da relação processual em consonância com o princípio da igualdade pensado de forma recíproca. Essa restrição se refere à impossibilidade da participação do réu na fase preliminar do processo, uma vez que, ao ser concedida a tutela provisória de urgência antecipada pelo modelo atual, o demandado fica submetido a uma decisão sem que tenha previamente participado do debate processual e contribuído com o resultado da decisão em respeito ao princípio da cooperação

1 Errata: a versão original do presente artigo omitiu o nome de Cynara Silde Mesquita Veloso do rol de seus autores. Embora a omissão não tenha decorrido de erro causado pelo periódico, estamos republicando o referido artigo, já no início de agosto de 2017, a pedido da parte interessada, a fim de sanar a omissão.

* Doutor em Ciências Jurídicas e Sociais pela Universidad Del Museo Social Argentino-UMSA. Professor Orientador do Centro de Pesquisa da Funorte em Montes Claros-MG. E-mail: <eeddmilson@ig.com.br>.

** Doutora em Direito Processual pela PUCMinas, Docente do Curso de Direito das Faculdades Integradas Pitágoras em Montes Claros-MG. E mail: <cynarasilde@yahoo.com.br>. 
e do contraditório, alinhados ao poder de influência atinente ao direito das partes. Por conseguinte, o estudo considerou também que a tutela antecipada da forma como é normatizada, embora seja uma alternativa para "o autor que tem razão" - na expressão cunhada por Marinoni; não se mostra razoável, dentro da perspectiva do devido processo legal. Diante disso, pode-se concluir que a tutela provisória de urgência antecipada deve ser aperfeiçoada e, com isso, acrescentar a audiência de justificação prévia obrigatória na fase inicial do processo no qual será respeitado o princípio do contraditório, da ampla defesa e da isonomia.

Palavras-chaves: Tutela provisória de urgência antecipada. Teoria neoinstitucionalista do processo. Contraditório. Isonomia. Ampla defesa.

\section{INTRODUÇÃO: O PARADIGMA DA TUTELA PROVISÓRIA}

A tutela provisória é um conceito novo criado para compor o rol de direitos processuais previstos no Novo Código de Processo Civil de 2015 (NCPC/2015) que entrou em vigor no ordenamento jurídico brasileiro em 18 de março de 2016 por meio da Lei n. 13.105/2015. Essa nova forma de tutela jurisdicional de cognição sumária tem previsão indicada nos artigos 294 a 311 do NCPC/2015. Embora com nomenclatura moderna, a nova lei processual trouxe reminiscência da tutela antecipada, prevista no art. 273 da lei processual ora revogada de 1973 (CPC/73) e da tutela cautelar alocada no art. 796 e seguintes do CPC/73 outrora revogado.

Cumpre destacar que, dentro do gênero tutela provisória, que engloba as tutelas de urgência e evidência, o campo de análise será atinente à tutela provisória de urgência, sendo essa ramificada pelas tutelas provisórias de urgência cautelar e antecipada. Todavia, o foco do trabalho se abstém das demais espécies para centrar-se na abordagem da tutela provisória de urgência antecipada, objeto de estudo em questão.

É importante salientar, outrossim, que o intento deste trabalho é analisar a tutela provisória na modalidade de urgência, com ênfase na tutela antecipada a partir da sua adequação aos princípios constitucionais do devido processo legal, quais sejam: os princípios do contraditório, da isonomia e da ampla defesa. É de todo proveitoso ressaltar que o desiderato aduzido é trazer uma discussão sobre o tema susodito e confrontar a teoria instrumentalista que instituiu a tutela provisória com a teoria crítica denominada de teoria neoinstitucionalista do processo.

Ainda nesse linear, é de suma importância ponderar que a tutela provisória de urgência antecipada necessita de uma reflexão e um aprimoramento. Embora seja um instituto de suma importância para o ordenamento brasileiro, na perspectiva da teoria instrumentalista do processo vinculada ao esteriótipo da celeridade na perspectiva do autor que não pode suportar o ônus do tempo. Como contraponto 
dessa análise, entende-se que a tutela provisória de urgência antecipada, para ser compatível com o devido processo legal, necessita de adaptações, visto que a decisão liminar em discussão entabulada no NCPC/2015 não cria como regra a participação da parte adversa no limiar do processo, precedentemente à decisão judicial. Esse fenômeno representa uma relativização ao princípio constitucional do contraditório, que irrompe contra a teoria de Fazzalari ${ }^{1}$ que visualizara o processo como sendo um procedimento em contraditório.

Nessa perspectiva, a decisão solipsista do julgador apresentada não tem compatibilidade com direito ao acesso à justiça em sua plenitude, pensada em uma dinâmica bilateral, isto é, direito de ação e direito de exceção. Essa reflexão cria mecanismos de análise sobre o princípio da igualdade de condições entre as partes e também em relação à aplicabilidade da paridade de armas prevista no art. $7^{\circ}$ do NCPC/2015 e ao princípio da cooperação. Esse axial é o escólio do poder de influência das partes rechaçado pela decisão do magistrado perspectivada unilateralmente. À luz desses fundamentos, o que se questiona no presente trabalho é se a tutela provisória de urgência antecipada prevista no NCPC/2015 está de acordo com o Estado Democrártico de Direito. Observa-se com agudeza, por meio da pesquisa em análise, que o instituto da tutela de urgência antecipada necessita da inclusão no texto normativo de garantias constitucionais do contraditório, da ampla defesa e da isonomia para que os litigantes tenham condições de manifestar-se antes da decisão, respeitando-se, assim, o poder de influência trazido pelas partes ao processo.

\section{A TUTELA PROVISÓRIA DE URGÊNCIA ANTECIPADA}

\subsection{A TIPOLOGIA DA TUTELA ANTECIPADA}

O instituto da tutela antecipada no novo Código de Processo Civil de 2015² ganhou uma nova roupagem e se constitui como um arcabouço denominado de tutela provisória que abarca 3 (três) tipos de tutela: a tutela antecipada, a tutela cautelar e ,por fim, a verdadeira novidade, ${ }^{3}$ a tutela de evidência. Direcionando o foco para a tutela antecipada, percebe-se que o conceito de tutela antecipada pode ser delineado por um primeiro significado que, vindo à tona, pode-se questionar: o que se antecipa, antecipa-se o quê? Em termos de vocabulário, significa fazer chegar ou ocorrer antes do tempo marcado, adiantar-se. ${ }^{4}$ Como explica Carmingnani, o sentido de tutela antecipada: "[...] depreende-se do próprio significado da palavra, adiantar os efeitos da tutela que será concedida, ao final, satisfazendo a própria pretensão do autor, ainda que provisoriamente [...]." ${ }^{{ }_{5}}$

Para Zavascki, ${ }^{6}$ o que se antecipa ao requerer a tutela é a eficácia social e não a jurídico-formal. No mesmo itinerário, Lopes ${ }^{7}$ destaca a natureza interlocutória da tutela antecipada. Nota-se, pois, que a afirmação desse autor advém do esclarecimento de que não se trata 
esse instituto de uma sentença ou de julgamento antecipado do conflito, mas "de medida de caráter provisório que visa a tutelar mais eficaz e prontamente o direito do autor sempre que ele preencher os requisitos exigidos pela lei."

É de todo conveniente assentar que, para concessão da tutela provisória de urgência antecipada, devem ser levados em conta os pressupostos de admissibilidade, ancorados na probabilidade do direito previsto tanto para tutela antecipada como para a tutela cautelar e no perigo de dano ou o do risco ao resultado útil ao processo. Esses últimos requisitos contemplam respectivamente a exigência para a tutela antecipada e cautelar, respectivamente.

Ainda sobre a tutela provisória, destaca-se que os requisitos para a tutela de urgência e para a tutela evidência são diferentes. Nessa toada, percebe-se que a tutela de urgência contempla como requisito a probabilidade do direito e o perigo de dano ou risco de resultado útil ao processo. Em outra direção, está a tutela de evidência, que tem requisitos específicos do art. 311 do NCPC/2015 e, independentemente do perigo de dano ou risco de resultado útil ao processo, haverá concessão da medida.

De modo esquematizado, segue o quadro 1 com os institutos ora denominados como forma de ratificar o alhures epigrafado:

\begin{tabular}{|c|c|}
\hline \multicolumn{2}{|c|}{ Tutela Provisória } \\
\hline Urgente & \multirow{2}{*}{ Evidente } \\
\hline Antecipada Cautelar & Art. 311 \\
\hline \multicolumn{2}{|c|}{ Probabilidade do Direito } \\
\hline $\begin{array}{r}\text { Perigo de Dano ou } \\
\text { Risco de Resultado Útil ao Processo }\end{array}$
\end{tabular}

Quadro 1 - Requisitos da Tutela Provisória

Fonte: elaboração própria (2016) com base no novo CPC/2015.

Dentro desse diapasão, é imprescindível destacar que o CPC/739 elencava como requisitos para a concessão da tutela antecipada: (i) a prova inequívoca e (ii) a verossimilhança da alegação. Quanto ao processo cautelar, os requisitos eram fumus buni iuris e periculum in mora. Esse conjunto de exigências de outrora representa o amálgama atual denominado de probabilidade do direito de um lado e perigo de dano ou risco de resultado útil ao processo de outro. Dessa forma, os requisitos, que antes eram específicos para cada tipo de tutela, foram aglutinados para os 2 (dois) tipos de tutela provisória de urgência, seja para a tutela antecipada, seja para a tutela cautelar.

Quanto ao contraditório, em decisão liminar, seja na tutela antecedente, seja na cumulativa com o processo principal, manteve-se o legislador renitente a sistemática de relativizar o direito ao contraditório do polo adverso. Nesse sentido, mister destacar que o ordenamento jurídico brasileiro tenta subverter a ordem e sistemática processual relativizando o contraditório entabulado outrora por Fazzalari, ${ }^{10}$ criando a figura do contraditório diferido. 
Adversamente, essa pretensão vem destituída de fundamentos perenes. Essa constatação é perfeitamente notada ao confrontar os requisitos utilizados para a concessão da medida antecipatória, que no $\mathrm{CPC} / 73^{11}$ exigia como requisito a prova inequívoca e a verossimilhança da alegação. Por conseguinte, no NCPC/2015 ${ }^{12}$, essa exigência é outra, denominada de probabilidade do direito e perigo de dano ou risco ao resultado útil ao processo. Nota-se, com esse enfrentamento, que o próprio legislador não foi capaz de sustentar os requisitos de outrora, qual seja, prova inequívoca e verossimilhança da alegação. Não sendo absurdo afirmar que esses requisitos do código revogado se demonstravam com uma interpretação muito particular e, quiçá, contraditória: ou seja, como a prova seria inequívoca e verossimilhante?

Entrementes, caminha-se para direcionar o estudo sobre as várias formas de tutela antecipada, sendo necessário trazer o escólio de vários doutrinadores como mecanismos para compreensão do sentido da tutela antecipada no ordenamento jurídico.

Nesse patamar, Melo $^{13}$ delineia a tutela antecipada como sendo a proteção ou o amparo antes do tempo que lhe seria próprio. Convém mencionar por oportuno que a sobredita autora lembra que, para a maioria dos autores, a tutela antecipada "é a decisão que antecipa alguns dos efeitos da sentença definitiva." ${ }^{14}$

Adstrito nessa clivagem, Leal ${ }^{15}$ define a tutela antecipada como a aplicação por antecedência dos "conteúdos tutelares da lei pelo ato sentencial interlocutório."

Para Mol, ${ }^{16}$ trata-se de uma técnica processual de adiantamento da proteção da lei ou uma forma de precipitação do tempo para a proteção da parte, tendo em vista o seu direito como visto por Carmignani. ${ }^{17}$

De modo consequente, na teoria do processo, os vários conceitos do que venha a ser a tutela provisória de urgência antecipada, parece haver uma unanimidade de que o seu significado está relacionado com uma medida de urgência ou com a prestação jurisdicional que visa a satisfazer o direito do autor antes do momento adequado, ou seja, da decisão final. Mas a definição de tutela provisória de urgência antecipada tem de ser pensada e problematizada no prisma da pragmática em que o significado da controvérsia tem acento nos sujeitos e na linguagem por meio da qual o leito da discussão se apresenta. $O$ fio condutor dessa dimensão é ratificado por Habermas ${ }^{18}$, que, por meio da razão comunicativa, apresenta a solução para a reconstrução de emaranhados de discursos formadores de opinião e preparadores de decisões onde está embutido o poder democrático exercido, conforme o direito.

\subsection{A TUTELA ANTECIPADA NO NOVO CÓDIGO DE PROCESSO CIVIL DE 2015}

A tutela provisória de urgência antecipada no NCPC/2015 ${ }^{19}$ está sob incipiente abordagem. Sendo assim, com a nova legislação, a tutela antecipada tornou-se uma espécie do gênero tutela provisória. Dessa maneira, a norma atualizada inovou ao trazer um aparato denominado de tutela provisória para antigas denominações de tutela antecipada e tutela 
cautelar, por meio de outro viés denominado de tutelas provisórias de urgência e evidência. Na primeira divisão (tutela provisória de urgência), comporta as tutelas já existentes no ordenamento jurídico brasileiro que são as tutelas antecipadas e tutelas cautelares, que se dão de 3 (três) maneiras (quanto ao peticionamento/protocolo/distribuição), que são as formas antecedente, cumulativa e incidental, conforme corroborado por Theodoro Junior. ${ }^{20}$ É importante reter na mente que a tutela antecedente representa uma novidade no NCPC/2015, ${ }^{21}$ visto que, no CPC/7322, essa possibilidade somente seria viável por meio da ação cautelar antecedente ou incidental. Partindo para a segunda divisão da tutela provisória, encontra-se a tutela provisória de evidência, que se efetiva por meio da distribuição de modo cumulativo. A obviedade do peticionamento ao processo de tutela de evidência tem como desiderato demonstrar que, nessa tutela, não existe o instituto, nem na forma antecedente, nem na forma incidental, uma vez que o pressuposto para a tutela de evidência é um raciocínio similar à "prova inequívoca”, que se efetiva por meio da prova pré-constituída.

Ainda dentro do mesmo estrato, deve ser destacado que o art. 311, inciso I, do NCPC/2015 23 trouxe a mesma redação do art. 273, inciso II, do CPC/7324, ora revogado, qual seja, "art. 311, inciso I - ficar caracterizado o abuso do direito de defesa ou o manifesto propósito protelatório da parte." Ademais, cabe tutela de evidência sempre que o autor na inicial produzir provas suficientes à constituição do direito e o réu não for capaz de trazer elementos que possam causar dúvida razoável. Não sendo demais asseverar que essa previsão é fruto de uma percepção cotidiana efetivada pelo réu em contestações completamente alheias ao pedido exordial.

De uma maneira geral, o legislador resolveu colocar debaixo de um mesmo arcabouço judicial a tutela provisória que engloba todas as espécies de tutela de urgência (antecipada e cautelar) e evidência, mas cada uma delas com as suas especificidades dentro do novo Direito Processual Civil.

Dentro desse viés, tem razão Bueno ${ }^{25}$ ao descrever de modo lapidar o conceito de tutela provisória caracterizando-se como um conjunto de técnicas que possibilitam uma decisão, atendidos determinados pressupostos que gravitam em torno da urgência e evidência. Sendo, portanto, prestada a tutela jurisdicional com base em decisão estável apta a assegurar ou a satisfazer desde logo o intento do autor no início da lide.

Sem embargos, encampadas na tutela provisória do novo texto processual, as várias espécies de tutelas careceriam de um estudo pormenorizado, contudo essa pretensão não é objeto do presente trabalho que passará a descrever de forma perfunctória as espécies de tutelas provisórias recaindo, assim, especificamente, na análise da tutela provisória de urgência antecipada, que receberá maior digressão.

Resulta, assim, confirmado que a tutela provisória é a soma de todas as tutelas denominadas de tutela de urgência e tutela de evidência. Devido à natureza abrangente do 
gênero tutela provisória, cumpre registrar a sua definição conforme está disciplinada pelo NCPC/2015.26

Nesse axial, conceitualmente, a tutela provisória é um aparato de técnicas que possibilitam ao magistrado de posse de determinados pressupostos, que circundam a presença da "urgência" ou da "evidência", prestar tutela jurisdicional, seja de forma antecedente, seja incidentalmente, com base em decisão instável (por isso, provisória) apta a assegurar e/ou a satisfazer rapidamente a pretensão do autor. ${ }^{27}$

No entendimento de Neves, ${ }^{28}$ a tutela provisória é proferida mediante cognição sumária porque o decididor, "ao concedê-la, ainda não tem acesso a todos os elementos de convicção a respeito da controvérsia jurídica”. Não obstante, destaca o sobredito autor que "excepcionalmente, entretanto essa espécie de tutela poderá ser concedida mediante cognição exauriente, quando o juiz a concede em sentença."

No que se refere à tutela provisória de urgência cautelar, disposta no art. $294 \mathrm{c} / \mathrm{c}$ art. 308, $\S 1^{\circ}$, do NCPC/2015, percebe-se que a concessão da medida se dá de 3 (três) formas, quais sejam: (i) de forma cumulativa ao processo principal, (ii) de forma incidental ou (iii) de forma antecedente. Já a tutela de evidência, esta se dá somente pela forma cumulativa, prevista no art. 311 do NCPC/2015.29

É de todo conveniente assentar que a tutela provisória de evidência tem suas particularidades divorciadas da tutela provisória de urgência, consequentemente, ao fazer uma leitura mais apurada sobre o novo instituto (tutela provisória), descobre-se que a tutela provisória de evidência fora tratada pelo legislador com certo descuido, que será analisado por meio de situações consignadas na sequência.

A primeira abordagem a ser feita sobre a tutela provisória de evidência é em relação à impossibilidade descrita sobre o pedido antecedente. Nesse diapasão, a legislação processual não autoriza pedido antecedente de tutela provisória de evidência, embora, para Neves, o pedido antecedente é plenamente possível, conforme escólio tratado a seguir: "O aspecto negativo [...] fica por conta da exclusão da tutela [provisória] de evidência como passível de ser concedida de forma antecedente". ${ }^{30}$ Além disso, arremata o autor susodito que a tutela provisória de urgência satisfativa e a tutela provisória de evidência se aproximam de forma significativa da tutela provisória de urgência antecipada (TPUA), já que a única diferença entre as tutelas se relaciona com os requisitos para sua concessão. Diante desse trivial, a satisfação fática é a mesma na tutela provisória de urgência antecipada e na tutela provisória de evidência. Insta destacar, pois, que Neves ${ }^{31}$ entende que a tutela provisória de evidência seria similar à tutela provisória de urgência antecipada, uma vez que ambas as decisões em relação aos institutos seriam acolhidas pela estabilidade prevista no artigo 304 cumulado com artigo 303 do NCPC/2015.32 Dentro desse mesmo norte, é de bom alvitre lembrar que somente será estabilizada a demanda se o réu não agravar de instrumento, sendo esse o escólio do caput do art. 304 que assim obtempera: 
"A tutela antecipada, concedida [...] torna-se estável se da decisão que a conceder não for interposto o respectivo recurso."

Não obstante o alegado pelo renomado doutrinador, referente à similaridade entre a tutela antecipada e a tutela de evidência, nota-se que a discordância com o tema é inequívoca, pelo seguinte motivo: a incongruência da necessidade de tutela provisória de evidência antecedente está presente na desnecessidade em patrocinar a documentação para o pedido principal entabulado no artigo 311, incisos II e III, do NCPC/2015.33 Explica-se: na tutela provisória de urgência antecipada antecedente, necessita-se da probabilidade do direito e do perigo de dano ou risco de resultado útil ao processo, já na tutela provisória de evidência, não há as exigências susoditas, apenas provas previamente constituídas, sendo, portanto, despiciendo o pedido antecedente na tutela de evidência, sendo essa a lógica pensada pelo legislador ordinário.

Em relação à tutela provisória de urgência antecipada, objeto do presente artigo, atualmente, está sob o manto da legislação do NCPC/2015, ${ }^{34}$ mas possui antecedentes históricos. Essa espécie de tutela surgiu no ordenamento brasileiro no CPC/73, cuja reforma aconteceu, à época, por meio da Lei n. 8.952, de 13.12.1994 ${ }^{35}$ que trouxe, em seu artigo 273, a possibilidade de antecipação dos efeitos da tutela em todos os processos de conhecimento.

Curial asserir, pois, que o instituto da antecipação dos efeitos da tutela, precedente à TPUA, representara prática corriqueira do dia a dia forense.

Dentro desse panorama, a tutela antecipada vai sendo construída e amoldada em busca de uma efetividade da jurisdição que coloca em conflito a razoável duração do processo e o devido processo legal.

\section{AS DIFERENTES FORMAS DE TUTELA PROVISÓRIA}

Para analisar a tutela provisória e suas espécies, é necessário um estudo comparativo entre os institutos a fim de evidenciar as similitudes e diferenças entre as modalidades da tutela provisória. Por conseguinte, nota-se que a tutela provisória de urgência cautelar objetiva a proteção do processo, já a tutela provisória de urgência antecipada tem como intento "a antecipação dos efeitos do resultado." ${ }_{36}$ Nessa direção, o ensinamento de Bueno ${ }^{37}$ traz a definição de tutela provisória de urgência cautelar e tutela provisória de urgência antecipada com o seguinte comentário: a tutela provisória cautelar deve ser compreendida como uma técnica que busca assegurar o resultado útil ao processo. Em outro sentido, a tutela provisória antecipada é responsável pela técnica que intenta satisfazer, desde logo, a pretensão obtemperada pelo autor da demanda.

É importante destacar que as tutelas provisórias de urgência, seja antecipada, seja cautelar, podem ser concedidas de forma antecedente ou de forma incidental. Essa possibilidade constitui a redação do art. 294 do NCPC/2015, que assim obtempera, in verbis: art. 294. "A tutela provisória pode fundamentar-se em urgência ou evidência. Parágrafo único. A tutela 
provisória de urgência, cautelar ou antecipada, pode ser concedida em caráter antecedente ou incidental." ${ }_{38}$

Crivado na mesma entonação, a tutela provisória de urgência antecedente (cautelar ou antecipada) é utilizada quando ainda não há processo principal. No mesmo trilho, a tutela provisória de urgência incidental é constituída por meio de uma mera petição protocolada nos autos do processo já em curso, denominado de processo principal (cautelar ou antecipada).

Como consequência da abordagem da tutela de urgência que o NCPC/2015 ${ }^{39}$ trata como similares em termos procedimentais (a tutela cautelar e a tutela antecipada), não há dúvida de que a natureza jurídica das sobreditas espécies de tutela de urgência, conforme lições de $\mathrm{Neves}^{40}$, não podem ser modificadas pela vontade do legislador.

Nessa quadra de ideias, a distinção dos institutos, embora considerados similares em determinada rubrica, permanece inalterada a diferença entre a tutela cautelar como garantidora do resultado útil e eficaz do processo e a tutela antecipada representando como desiderato fundamental à satisfativa do direito da parte no plano fático.

Não sendo novidade sufragar que a tutela antecipada e a tutela cautelar, embora com nova nomenclatura e requisitos modificados, se comparados com o texto da lei precedente de 1973, é inequívoco que a abrangência e a finalidade delas continuam inalteradas.

\section{A TUTELA ANTECIPADA E A TEORIA NEOINSTITUCIONALISTA DO PROCESSO}

A proposta deste artigo visou a uma análise da tutela provisória de urgência antecipada na visão da teoria neoinstitucionalista do processo por entender que é relevante o instituto em questão, por esse carecer de um olhar para além dos muros das doutrinas institucionalistas processuais as quais instituíram tal procedimento. Além disso, a escolha de tal teoria justifica-se porque o instituto da tutela necessita de uma visão mais crítica devido a sua incompatibilidade com os princípios que se vinculam ao Estado Democrático de Direito.

A constatação de que a tutela antecipada não compatibiliza com os princípios dignos de um Estado Democrático de Direito está demonstrada no desrespeito aos princípios do contraditório, da isonomia e da ampla defesa.

Nesses termos, por não se vincular a tais desideratos, faz-se mister adequar a tutela com o modelo contemporâneo de Estado, e, para tanto, cabe aqui uma dose de criticidade, com o auxílio da teoria neoinstitucionalista do professor e doutrinador Rosemiro Pereira Leal, que traz uma abordagem diversa do sistema processual dominante, encantador instrumentalista, no qual foi gestada a tutela de outrora, denominada atualmente de tutela provisória.

Em virtude desse procedimento padrão, o sistema jurídico brasileiro, no quesito tutela antecipada, não coaduna com o Estado Democrático de Direito, já que não confere às partes 
total igualdade na relação processual. Isso porque, de acordo com Mattos, ${ }^{41} \mathrm{o}$ formalismo moderno ocidental preconizado para a aplicação das normas jurídicas contempla um formalismo conjugando um caráter genérico e abstrato para aplicação no caso concreto, sendo distante do mundo ético e político materialmente consubstanciado.

A teoria neoinstitucionalista, de acordo com Leal, ${ }^{42}$ questiona esses aspectos existentes no sistema processual brasileiro dotado de um Direito normatizado e dogmático, distante do caráter contínuo e problematizante implícito no conhecimento jurídico. Dentro desse contexto e em nome de uma celeridade ao procedimento, no caso da tutela antecipada, o rito procedimental acaba por, em virtude da demanda, radicalmente beneficiar o autor, que sempre terá razão, e prejudicar o réu, que nunca tem razão, contrariando o devido processo legal.

Para uma melhor definição da teoria neoinstitucionalista do processo, diz Leal ${ }^{43}$ que se trata de uma "Teoria da processualização testificante da validade normativo-democrática, porque propõe e atua um pensar jurídico na racionalidade sempre problematizável, por falibilidades revisíveis, da produção e aplicação do direito”.

Em comento ao conceito acima, Veloso ${ }^{44}$ acrescenta que, nos moldes apontado por Leal, "[...] o processo é um modelo construído com base na constituição e com ampla participação da comunidade jurídica na construção do provimento". ${ }^{45}$

Nesse sentido, esclarece Leal ${ }^{46}$ que a teoria neoinstitucionalista do processo "não é uma ordem de pensamento acabado. Erige-se de um apelo crítico-participativo das partes juridicamente legitimadas à instauração de procedimentos em todos os domínios da jurisdicionalidade".

Além disso, ainda acrescenta o doutrinador que a marca distintiva da teoria neoinstitucionalista do processo em relação à teoria constitucionalista é a proposta de uma teoria oriunda de "um espaço processualizado" e, portanto, uma teoria comprometida "com a teorização do Direito Democrático, tornando-se impraticável num regime jurídico que esteja ainda identificado com os velhos conceitos de Estado de Direito ou Estado Social de Direito”. ${ }^{47}$

Diante da pluralidade de perspectivas doutrinárias que se divergem no campo do Direito Processual no qual se insere a tutela, podem ser identificados alguns posicionamentos que divergem da teoria neoinstitucionalista, que será bem detalhada adiante.

Ao que se percebe, a tutela antecipada como técnica processual foi criada com o fito de antecipação da proteção da legislação como quebra do paradigma do reconhecimento do direito material somente após decisão exauriente ou para a satisfação do direito como demonstra o art. 273, I ou II, do CPC/197348 (os requisitos para a concessão da tutela antecipada ora revogados).

Conforme estabelece a legislação, a concessão da tutela antecipada é proferida (in limine litis), o que significa que esse instituto possui caráter liminar, ou seja, ocorre no início do 
processo. Não se pode esquecer de que o objetivo de tal pretensão é a satisfação do direito por meio da precipitação do tempo. Dessa forma, o julgamento antecipado de um problema ou de uma lide se dá "de forma a se alcançar a efetividade do processo de maneira mais rápida e completa possível”. ${ }^{49}$

Como se observa da doutrina sobre a tutela antecipada, esse instrumento de urgência emerge como prestação jurisdicional com traços de procedimento que procura, em detrimento da morosidade da justiça, solucionar os conflitos de modo a abreviar o tempo, a dar efetividade ao processo com o discurso do contraditório postergado.

Diante desse fenômeno, Feres ${ }^{50}$ ao discorrer sobre o assunto da tutela, entende que, caso esta se encontre em meio à "demora do processo, motivada não apenas pelo sistema legal implantado, que inclui sistema de recursos morosos, mais por fatores de toda ordem, inclusive pelo excesso de causas distribuídas, causa prejuízo às partes, desacreditando a justiça e sua finalidade de solucionar conflitos".

No mesmo sentido, Bueno ${ }^{51}$ é adepto de uma tutela antecipada como mesmo diz "sempre adorei, mesmo antes de ela 'existir' no CPC [de 1973], pelo menos de forma expressa [...], sempre me fascinaram as enormes dificuldades de sua interpretação sistemática”.

$\mathrm{Na}$ visão de Bueno, ${ }^{52}$ a tutela antecipada é uma forma de simplificar muito as ações dentro do Processo Civil brasileiro, que recebeu o credenciamento para que o procedimento em uma lide passasse a "começar do fim para o começo (da satisfação de seus resultados para a confirmação desses mesmos resultados)".

Nesses termos, com a tutela antecipada, vislumbra-se o legislador promover, por meio da celeridade e da efetividade do processo, o direito material em uma satisfação do direito em tempo recorde.

Com essa compreensão, fica evidente que, pelas normas que regem a tutela, esse meio processual surge com o intuito de beneficiar o autor na suposição de um direito que mostre provável, razão que justificaria a manifestação deste em obter a medida.53

Oportuno, nesse ínterim, trazer o escólio de Medina $^{54}$, que assim destaca sobre o tempo do processo que representa uma fisiologia processual e fonte de dano para o autor que tem razão no pleito. Pensar divorciado dessa premissa é patrocinar o custo das delongas processuais como de responsabilidade aduzida ao autor.

Na mesma direção de Lopes, ${ }^{55}$ é o entendimento de Alvim, ${ }^{56}$ que levanta a tese da bilateralidade das audiências (audia tur et altera pars) para que se dê possibilidade de oitiva do réu.

A pesquisa aponta que, com a concessão da liminar, certos paradoxos que ensejam conflitos de direitos fundamentais. Isso devido às regras (de um Estado autoritário) impostas para tal benefício tutelar. Como destaca Bueno, ${ }^{57}$ "a tutela antecipada é instituto que, por definição, prestigia muito mais o autor do que o réu". 
Com esse norte e com o conhecimento das questões preconizadas, é que a doutrina vem entendendo e justificando a existência de tutelas de urgência. Conforme Feres, ${ }^{58}$ as diretrizes e normas estabelecidas pelo legislador "devem ser fielmente observadas, de forma a garantir o princípio da segurança jurídica”.

Em nome dessa segurança jurídica, a técnica processual da tutela antecipada:

[...] tende muito mais à realização concreta do princípio da efetividade da jurisdição do que do princípio do contraditório ou do devido processo legal, quando analisados, parcialmente, como garantia para o réu, única e exclusivamente. Dito de forma bem simples, a tutela antecipada é instituto que [...] depois de séculos de tradição de um processo que, em nome [...] da segurança jurídica que ele representa, prestigiou muito mais $[. .$.$] o autor. { }^{59}$

Com essa concepção de que, na tutela, predomina o princípio da efetividade da jurisdição, é que se volta única e preponderantemente para o autor, possibilitando evidenciar o aspecto instrumental do direito processual, que acaba sufocando os princípios do contraditório, da ampla defesa e da isonomia, além do devido processo constitucional.

Por hora, resta acrescentar a esse cômputo pesquisacional sobre tutela antecipada que a teoria neoinstitucionalista do processo defende a ideia de que o Direito deveria ser construído em uma participação popular, consubstanciando no debate efetivado pelos próprios destinatários da norma, estabelecendo-se uma criação e aplicação sempre de forma participativa. ${ }^{60}$

Em uma mesma linha de raciocínio, Veloso, ${ }^{61}$ ao analisar a teoria neoinstitucionalista do processo, enfatiza o aspecto da participação do povo no processo jurídico defendido por tal perspectiva teórica. Conforme a autora sobredita, o que a teoria neoinstitucionalista do processo visa é uma "sociedade jurídico-político-democrática em que o direito possa ser garantido por meio de relações dialógicas de liberdade e igualdade do homem perante o Estado".62

Ainda de acordo com Veloso, ${ }^{63}$ a teoria crítica em comento, que tem como enfoque os contornos e a decisão democrática:

Consiste em uma proposição que possibilita compreender de que maneira ocorre a transposição do princípio do discurso em princípio da democracia, suprindo a lacuna deixada por Habermas em sua obra Direito e Democracia: entre facticidade e validade. Além disso, Leal, por meio da sua teoria neoinstitucionalista, objetiva construir um referente lógico-jurídico capaz de submeter a testes as teorias que se intitulam de democráticas.

Como aponta a teoria neoinstitucionalista do processo elaborada por Leal, ${ }^{64}$ é preciso que os provimentos que se referem às decisões, às leis e às sentenças decorrentes tenham como resultado o diálogo processual em sintonia com a comunidade jurídica constitucionalizada em todas as fases de criação, alteração, reconhecimento e aplicação de direitos e que 
jamais seja efetivada por meio de poderes autoritários dos órgãos dirigentes, legiferantes e jurídicos seja do Estado ou da comunidade.

Para Leal, ${ }^{65}$ o Direito deve ser exercido na sua plenitude constitucional, o que exige uma participação crítica das partes juridicamente legitimadas. Desse modo, de acordo com o autor, não é possível alcançar uma cidadania plena somente quando houver o nivelamento de todos no procedimento. Assim, na lide, os conflitantes devem se valer dos princípios do contraditório, da ampla defesa e da isonomia.

Referente à tutela antecipada, o professor Leal ${ }^{66}$ admite que tal procedimento, quando não observados os aspectos de constitucionalidade democrática, corresponde ao maior e velho amigo da ditadura no Direito processual brasileiro.

Nunca é demais destacar que a tutela antecipada, ao satisfazer o direito material sem o devido contraditório, relativiza o devido processo legal com o fetiche do ônus do tempo. Essa realidade faz o personagem (ônus do tempo) ser o subterfúgio responsável para colmatar o princípio da igualdade pensada não em sentido de postergação do contraditório, mas sim completamente desvinculado ao direito ao contraditório analisado sob a temática da reciprocidade.

Em virtude dessa desigualdade de condições procedimentais, a lei processual é assediada pela praticidade instrumental. Para Leal, ${ }^{67}$ autor e réu não estão aglutinados em uma igualdade defensiva, provocando uma polissemia incontornável na teorização do Direito processual brasileiro. Essa situação lacônica da lei é causa de grande perplexidade nos processualistas que são avessos ao praxismo judiciário.

Seguindo a linha de raciocínio da teoria da decisão jurídica de Leal, ${ }^{68}$ o presente trabalho reafirma o seu compromisso em defesa da criação da audiência de justificação prévia obrigatória para a oitiva do réu. Com esse propósito, mediante a abertura do contraditório, é que, segundo Leal, ${ }^{69}$ legitima-se a antecipação de tutela a partir do momento em que são atendidos os direitos fundamentais do processo.

Com essas questões, diz Leal ${ }^{70}$ que é necessário questionar os pressupostos da justiça que se quer rápida para assegurar a efetividade. Nesse sentido, o Autor susodito reforça que:

Seria, portanto, absurdo imaginar que a solução de conflitos, no Estado Democrático, pudesse ser obtida com postergação (renúncia) de direito fundamental, a pretexto de realização da justiça pelo juiz talentoso. Se o acordo é obtido com aviltamento (desbalanceamento procedimental) de uma das partes, quebra-se o princípio da isonomia, do contraditório, da ampla defesa, por induzir-se ao acordo ou a desestimulá-lo ao debate em face dos custos de um advogado, quando impossível um defensor público, ou pela morosidade das demandas. A conciliação das partes, nessas circunstâncias, equivale a coonestações explicitas com a omissão do Estado em prestar atividade de jurisdição gratuita pelo Processo a serviço da cidadania (art. 50, LXXVII CF/1988). ${ }^{71}$ 
Uma das críticas de Leal ${ }^{72}$ em relação às tutelas de urgência é que há uma exaltação no que se refere à presteza dos institutos. De acordo com o Jurista, os procedimentos liminares são vistos como sendo atos mágicos que imersos na ambulância do Judiciário são capazes de socorrer de modo incondicional os direitos ameaçados ou lesionados.

Além disso, Leal ${ }^{73}$ observa também que, ao decidir pela tutela, o ato implica violação do instituto da ampla defesa, previsto no art. $5^{\circ}$, inciso LV, CF/1998..$^{74}$

Como disposto no artigo citado, a Constituição brasileira de 1988, norma máxima, assegura o contraditório e a ampla defesa, porém, como perfeitamente notado pela leitura de outrora, esses direitos não são observados, o que vai de encontro à lei supraconstitucional.

\subsection{O CONTRADITÓRIO, A ISONOMIA E A AMPLA DEFESA NA DEMOCRATI- ZAÇÃO DA TUTELA ANTECIPADA}

A Constituição da República Federativa do Brasil de 1988 contemplou, em seu artigo $5^{\circ}$, inciso, LIV,${ }^{75} \mathrm{o}$ devido processo legal, que deve ser o leito por onde deveriam caminhar todos os jurisdicionados em prol de uma justiça em que haja a garantia também do contraditório e a ampla defesa com os meios e recursos a ela inerentes.

Sem a observância dos princípios (contraditório, isonomia e ampla defesa) que são imprescindíveis para a realização do processo, não existe a possibilidade de se falar em Estado Democrático de Direito, mas em simples Estado poderoso, autoritário e que impõe a sua vontade.

Ao que se percebe, a tutela antecipada, não incluindo a oitiva do réu no seu procedimento incipiente, por meio da audiência de justificação prévia, cria um vácuo no contraditório, que compromete os princípios salutares sobre os quais discorre Dallari, ${ }^{76}$ uma vez que prejudica sobremaneira o próprio direito, qual seja, o direito de defesa, e prejudica o poder de influência, que é um atributo das partes.

Nesse quadro de circunstâncias, Lealn lembra que não há o que se falar em tutela antecipada legítima se não forem atendidos os direitos fundamentais do processo. Assim, o autor entende que nem sempre uma justiça rápida (como é o caso da tutela antecipada) é sinônimo de uma justiça justa.

Em consonância com Leal, ${ }^{78}$ Tucci ${ }^{79}$ destaca que a urgência enfraquece o contraditório. Isso porque propicia o estímulo das liminares cujo risco é o estímulo à tutela de urgência como uma justiça simplesmente.

Assim, o acesso à jurisdição, garantem Cruz e Tucci, ${ }^{80}$ deve-se iniciar não com a decisão, e sim com uma abertura a um tratamento igualitário perspectivado para os sujeitos do processo, como forma de oportunidades recíprocas entre os participantes. A igualdade destacada é condizente com a isonomia das partes seja em seus direitos, seja em relação à produção de provas, todas essas possibilidades ligadas ao mesmo tratamento para os litigantes. 
Na obra "Igualdade e Diferença: Estado Democrático de Direito a partir do pensamento de Habermas", Galuppo ${ }^{81}$ discute sobre o princípio jurídico da igualdade e assim responde o que representa esse princípio para o Estado Democrático de Direito. Na perspectiva de Galuppo, ${ }^{82}$ a resposta a essa questão não é simples, pois envolve certas variáveis, por exemplo, a variável escolha.

A crítica de Leal reside no fato de que fica difícil falar de princípio da igualdade ou do contraditório em um país como o Brasil, que tem um modelo de processo civil portador de uma linguagem ultrapassada ou, nas palavras do autor, "envelhecida e bolorenta", cuja versão é ortodoxa. Não obstante, exprime o jurista que, embora a Escola Processual Paulista fundada por Liebman desde o início, quando veio para o Brasil, seja calcada em bases Chiovendiana, Carneluttiana, outro paradigma ou modelo de ciência processual vem se despontando com novas conquistas ou perspectivas teóricas (como a teoria neoinstitucionalista do processo adotada nesse artigo) "em bases democráticas nacionais, supranacionais e mundiais do direito pós-moderno". ${ }^{83}$

Quanto ao princípio da igualdade ou da isonomia, Leal ${ }^{84}$ é enfático ao dizer que se refere ao direito-garantia hoje constitucionalizado em vários países de feições democráticas, e, além disso, trata-se de elemento indispensável do procedimento em contraditório (processo).

Na análise do autor, "a liberdade de contradizer no Processo equivale à igualdade temporal de dizer e contradizer para a construção, entre partes, da estrutura procedimental”. ${ }^{85}$

Diante dessa contextualização, é importante perceber que o NCPC/2015 $5^{86}$ embora tenha uma produção legiferante mais moderna e arquitetada para o respeito ao contraditório. Nota-se a firme ligação com o passado estabulado pelo modelo do Código de 1973. ${ }^{87}$ Essa percepção é constatada pelo artigo $9^{\circ}$, com a seguinte redação: "Art. 9으ão se proferirá decisão contra uma das partes sem que ela seja Previamente ouvida. Parágrafo único. $\mathrm{O}$ disposto no caput não se aplica: I - à tutela provisória de urgência; II - às hipóteses de tutela da evidência previstas no art. 311, incisos II e III". ${ }^{88}$

Diante do sobredito, não muito afastado da colocação tomada por mote, nota-se que o princípio da cooperação é totalmente desrespeitado, ratificando que o NCPC/2015, ${ }^{, 9} \mathrm{embora}$ buscando um Direito mais efetivo, contraria o pilar do processo que é diretamente ligado ao princípio do contraditório.

Cabe destacar que o Estado Democrático de Direito não se trata de algo pronto e acabado. Cumpre observar que o conceito não é estático, mas dinâmico, por isso, como a democracia é um complexo em construção em constante aperfeiçoamento, torna-se válido dizer, como afirma Madeira et al., ${ }^{90}$ que o processo é o garantidor e o aplicador do sentido e da justificação de um Direito democrático, com elementos jurídico-existenciais e princípios institutivos estabelecidos pelo contraditório, isonomia e ampla defesa.

Acrescenta-se à lição que o direito de ter o dever de ser fundado tão somente no prin- 
cípio democrático. Desse modo, o decidir não seria mais compreendido como um mecanismo liberal majoritário ou a partir de uma "pretensa vontade geral" do Estado. Dito isso, defende-se que o processo deve ser institucionalizado por "normas que garantam a possibilidade de participação discursiva dos cidadãos no processo de tomada de decisões." ${ }_{91}$

No entendimento de Almeida, ${ }^{92}$ há um liame entre o Estado de Direito Democrático com o Estado de Direito. Tal ligação está relacionada ao princípio da reserva legal. Todavia, explica a autora que, além dessa característica de conexão, há algo que vai além dos

[...] limites do Estado de Direito com um plus democrático, que significa garantia de participação efetiva dos destinatários estatais na sua criação aplicação e fiscalização por meio (medium linguístico-jurídico) da processualidade jurídica (isonomia, contraditório e ampla defesa). ${ }^{93}$

Em consonância com a processualidade jurídica de Almeida, ${ }^{94}$ Leal ${ }^{95}$ acrescenta que a isonomia, o contraditório e a ampla defesa estão no plano dos direitos de primeira geração. Ainda no escólio de Leal, em Direito Processual, não é inaplicável a regra da equidade no sentido lockeano, que significa "tratar iguais igualmente e desiguais desigualmente, porque o processo na Teoria do direito democrático é o ponto discursivo da igualdade dos diferentes, para estabelecer os critérios de formação de vontade". ${ }^{96}$

Para Tucci, ${ }^{97}$ a igualdade está intimamente vinculada ao devido processo legal, ao contraditório, à imparcialidade. A correlação do autor entre tratamento paritário e devido processo legal significa, no seu entendimento, que o processo é o reflexo dos objetivos do Estado, não sendo possível às partes ao bel-prazer de interesses e condutas ora em litígio. Ademais, entre os sujeitos do processo, devem ser conferidas igualdades de oportunidades como garantia de uma tutela adequada. Nesse sentido, deve o juiz sopesar as consequências de eventuais medidas relacionadas à parte contrária.

Registre-se que, conforme define Almeida, citado por Tucci, ${ }^{98}$ o conceito de contraditório é a expressão da ciência bilateral dos atos e dos termos do processo e a possibilidade de contrariá-los.

Para Leal, ${ }^{99}$ o contraditório é um princípio que se refere ao processo constitucionalizado, e, portanto, traduz-se em direito das partes ao acesso dialógico necessário à defesa e à disputa dos direitos em litígio, podendo, inclusive, exercer a liberdade de nada dizerem, mesmo tendo o direito-garantia de poder efetivamente manifestar.

Conclui o jurista neoinstitucionalista que, se ausente o princípio do contraditório, o processo "perderia sua base democrático-jurídico-principiológica e se tornaria um meio procedimental inquisitório em que o arbítrio do julgador seria a medida colonizadora das liberdades das partes". ${ }^{100}$

Com esse enfoque, discorre Tucci ${ }^{101}$ que é absolutamente incompatível com a isonomia e com os princípios da tutela jurisdicional um tratamento unilateral no processo, e, por isso, 
ao réu deve ser dado o direito de pedir denegação da tutela jurisdicional pedido pelo autor uma vez que não se conforma com o direito objetivo.

Em resumo, Tucci ${ }^{102}$ entende que a igualdade e o contraditório representam genuinamente os pilares da democracia, "na qual o moderno direito processual está completamente inserido."

O princípio da igualdade processual, de acordo com Cintra, Grinover e Dinamarco, ${ }^{103}$ brota do princípio da igualdade perante a lei, prevista no art. $5^{\circ}$, caput, da Constituição da República Federativa do Brasil de 1988.104

Além do art. $5^{\circ}$ da $\mathrm{CF} / 88,{ }^{105}$ podem-se encontrar outros dispositivos no Código que elegem o princípio da igualdade, a exemplo do art. 139, inciso I, do Código de Processo Civil de 2015, ${ }^{106}$ que assim propugna a competência do juiz para "assegurar às partes a igualdade de tratamento."

De acordo com Cintra, Grinover e Dinamarco, ${ }^{107}$ o processo civil é constituído por normas e mecanismos que possibilitam às partes litigarem com paridade de armas, cujo intento é estabelecer que nenhuma das partes tenha condições, seja de superioridade, seja inferioridade em face do outra.

No que se refere ao contraditório, Cintra, Grinover e Dinamarco ${ }^{108}$ defendem o princípio da audiência bilateral que, no sentido romano, se representa no brocardo audiatur et altera pars.

Em um processo dialético, representam as partes - tese (autor), réu (antítese) e Juiz (síntese). Nesse sentido, ressalta Mitidiero ${ }^{109}$ que o processo pressupõe uma complexidade pautada na argumentação, em que a cooperação é o liame entre o caráter apodítico eclipsado pela construção dialógica.

Assim, a dialética torna-se indispensável à concretização do Estado Democrático de Direito, ao possibilitar o contraditório, que, por sua vez, "é responsável pela garantia da ampla defesa". ${ }^{110}$

A ampla defesa é outro princípio a ser observado quando estão em discussão a antecipação de tutela e a teoria neoinstitucionalista do processo. Desse modo, para a teoria neoinstitucionalista do processo, o princípio da ampla defesa "é coextenso aos princípios do contraditório e da isonomia, porque a amplitude de defesa se faz nos limites temporais do procedimento em contraditório". ${ }^{111} \mathrm{O}$ jurista explica que a amplitude da defesa não quer dizer infinitude de produção de defesa a qualquer tempo, mas o direito de manifestar no processo em tempo adequado.

Nesse sentido, o significado de ampla defesa, na visão do autor, diz respeito a algo que não pode ser comprimida ou estreitada pela sumarização do tempo a tal ponto de excluir a liberdade de reflexão cômoda dos aspectos fundamentais de sua produção eficiente. ${ }^{112}$

Diz ainda o autor que o princípio da ampla defesa ou o seu curso normal do tempo não podem ser sacrificados, a pretexto da celeridade processual ou efetividade do processo. ${ }^{113}$ Há 
de ser observado, nesse contexto, que a tutela antecipada sem a concessão da ampla defesa acaba por suprimir o direito da outra parte, uma vez que a decisão, nesse procedimento antecipatório sumário, é rápida, não aprofundada, o que não dá chances ao demandado de se defender em tempo e modo suficientes para demonstrar o seu direito como forma de influenciar na decisão.

A pesquisa aponta que a tutela antecipada vai de encontro ao que está previsto na Constituição Federativa do Brasil de 1998, lei maior que rege o País. O texto constitucional previu os princípios do contraditório e da ampla defesa no mesmo artigo (art. $5^{\circ}$, inciso LV), o qual determina que "aos litigantes, em processo judicial ou administrativo, e aos acusados em geral são assegurados o contraditório e a ampla defesa, com os meios e recursos a ela inerentes". ${ }^{114}$

Para a teoria neoinstitucionalista do processo, a ampla defesa inscrita no art. $5^{\circ}$, inciso LV, da Constituição da República Federativa do Brasil de 1988, deve possibilitar uma "concepção expansiva da negação ou afirmação de constitucionalidade dos atos e conteúdos jurídicos das pretensões e de sua procedimentalidade formal [...].115

Acrescenta-se, ainda, que a ampla defesa está inserida em uma perspectiva mais abrangente que, de acordo com Marinoni"116 "é a do devido processo legal." Conforme o autor em referência, ${ }^{117}$ a ampla defesa deve ser sempre pensada em contraponto com o direito à tempestividade e à efetividade da tutela jurisdicional que são os corolários do direito de ação expressamente garantido no artigo $5^{\circ}$, inciso XXXV, da Constituição da República Federativa do Brasil de 1988. ${ }^{118}$

\section{CONCLUSÃO}

Neste trabalho, objetivou-se, de modo geral, analisar se a tutela antecipada vai ao encontro do Estado Democrático de Direito a partir da sua adequação aos princípios constitucionais do devido processo legal, ou seja, do contraditório, da isonomia e da ampla defesa.

Diante dessa circunstância, nota-se que esse instituto não está em consonância com a abertura de um espaço discursivo processualizado, uma vez que não inclui a participação do réu no processo em sua fase inicial.

O estudo constatou que a TPUA não se ajusta aos princípios do Estado Democrático de Direito, visto que há uma supressão das garantias processuais do contraditório, da isonomia e da ampla defesa em prol de uma das partes sob o fundamento prematuro da probabilidade do direito aliado ao perigo de dano ou o risco ao resultado útil do processo.

Ao que se percebe, a tutela provisória de urgência antecipada pensada na perspectiva da probabilidade do direito contraria os princípios da isonomia, do contraditório e da ampla defesa e, consequentemente, cria uma anomalia ao devido processo legal. Não sendo demais 
destacar que esses elementos são essenciais para que seja garantido um Direito democrático, em que haja a participação de todos os demandantes nos ritos procedimentais, principalmente na fase inicial do processo, como mecanismo de contribuir de forma democrática na decisão a ser efetivada em respeito ao poder de influência dos litigantes atrelado ao princípio da cooperação consubstanciado no NCPC de 2015.

Tomando como pressuposto a teoria neoinstitucionalista do processo do professor Rosemiro Pereira Leal, foi possível averiguar que, uma vez instituída, dentro do arcabouço jurídico brasileiro, a instrumentalidade do processo, os aspectos normativos que regem a tutela provisória de urgência antecipada não estão adequados a um contexto da pós-modernidade. Os resultados da pesquisa permitiram responder que o campo do Direito é facilmente passível de questionamentos das suas verdades absolutas, sobretudo quando não há, como se observou, o contraditório que, segundo Tucci, ${ }^{11}{ }^{19}$ indica "precisamente no direito de participação no processo, mediante a utilização de todas as armas legítimas e disponíveis destinadas a convencer o julgador a outorgar um julgamento favorável a quem tem um direito".

Assim, necessária, pois, a inclusão da participação das partes como forma de validar o Estado da pós-modernidade, não somente de Direito, mas do Estado Democrático de Direito.

De acordo com a teoria neoinstitucionalista do processo, o espaço processual deve dar garantia ao debate entre as partes, na medida em que deve possibilitar aquilo que já previa os romanos no brocardo auditur auter pars. Essa perspectiva retira a figura do juiz Hércules, que, com seus poderes, decide não dar ao réu espaço à discursividade. Desse modo, ao réu deve ser dado o direito de participar de todas as fases do processo, de modo a ter uma ampla defesa que o permita estar em paridade de armas com a parte adversa.

Considera-se, nesse estudo, que a tutela provisória de urgência antecipada deverá ser apreciada mediante a participação do réu, sendo-lhe permitida uma audiência de justificação prévia obrigatória. Por isso é que se defende a necessidade da audiência de justificação prévia obrigatória como forma de o réu poder manifestar no processo, sob pena de uma decisão solipsista e desconectada com a dialogicidade.

\section{REFERÊNCIAS}

ALMEIDA, Andréa Alves de. Processualidade jurídica e legitimidade normativa. Belo Horizonte: Fórum, 2005.

BARACHO, José Alfredo de Oliveira. Direito processual constitucional: aspectos contemporâneos. Belo Horizonte: Fórum, 2008.

BASTOS, Celso Ribeiro. Curso de direito constitucional. 17. ed. São Paulo: Saraiva, 1996. BRASIL. Lei n ${ }^{\circ}$ 5.869, 11 de janeiro de 1973. Revogado pela Lei n. 13.105 de março de 2015. Institui o Código de Processo Civil. Presidência da República, Brasília, DF. Disponí- 
vel em: <http://www.planalto.gov.br/ccivil_03/leis/L5869.htm>. Acesso em: 19 jan. 2017. . Constituição (1988). Emenda constitucional no 91, de 2016. Presidência da República, Brasília, DF. Disponível em: <http://www.planalto.gov.br/ccivil_03/constituicao/ constituicao.htm >. Acesso em: 20 jan. 2017.

. Lei no 8.952, de 13 de dezembro de 1994. Altera dispositivos do código de processo civil sobre o processo de conhecimento e o processo cautelar. Presidência da República, Brasília, DF. Disponível em: <http://www.planalto.gov.br/ccivil_03/leis/L8952.htm>. Acesso em: 26 jan. 2017.

. Lei nº 13.105 , de 16 de março de 2015. Código de Processo Civil. Presidência da República, Brasília, DF. Disponível em: <http://www.planalto.gov.br/ccivil_03/_ato20152018/2015/lei/L13105.htm>. Acesso em: 19 jan. 2017.

BUENO, Cassio Scarpinella. Tutela antecipada. São Paulo: Saraiva, 2004.

BUENO, Cassio Scarpinella. Manual de direito processual civil. 2. ed. São Paulo: Saraiva, 2016.

CARMIGNANI, Maria Cristina da Silva. A origem romana da tutela antecipada. São Paulo: LTR, 2000.

CINTRA, Antonio Carlos de Araújo; GRINOVER, Ada Pellegrini; DINAMARCO, Cândido Rangel. Teoria geral do processo. 28. ed. São Paulo: Malheiros, 2013.

DALLARI, Dalmo de Abreu. O poder dos juízes. São Paulo: Saraiva, 1996.

DINAMARCO, Cândido Rangel. A instrumentalidade do processo. 11. ed. São Paulo: Malheiros, 2003.

FAZZALARI, Elio. Instituições de direito processual. Tradução Elaine Nassif. Campinas: Bookseller, 2006.

FERES, Carlos Roberto. Antecipação da tutela jurisdicional. São Paulo: Saraiva, 1999.

GALUPPO, Marcelo Campos. Igualdade e diferença: estado de democrático de a partir do pensamento de Habermas. Belo Horizonte: Mandamentos, 2002.

HABERMAS, Jürgen. Direito e democracia: entre facticidade e validade. 2. ed. Tradução Flávio Beno Siebeneichler. Rio de Janeiro: Tempo Brasileiro, 2003. v. 1.

LASPRO, Oreste Nestor de Souza. Garantia do duplo grau de jurisdição. In: TUCCI, José Rogério Cruz e. Garantias constitucionais do processo civil. São Paulo: Revista dos Tribunais, 1999.

LEAL, Rosemiro Pereira. Teoria processual da decisão jurídica. São Paulo: Landy, 2002.

LEAL, Rosemiro Pereira. Teoria geral do processo. 6. ed. São Paulo: IOB Thomson, 2005. p. 98. 
LEAL, Rosemiro Pereira. Teoria geral do processo: primeiros estudos. 12. ed. Rio de Janeiro: Forense, 2014.

LOPES, João Batista. Tutela antecipada no processo civil brasileiro. 4. ed. São Paulo: Saraiva, 2009.

MADEIRA, Dhenis Cruz et al. Processo, jurisdição e ação em James Goldschmidt. In: LEAL, Rosemiro Pereira. Estudos continuados de teoria do processo: a pesquisa jurídica no curso de mestrado em direito processual. Porto Alegre: Síntese, 2005. v. 6.

MARINONI, Luiz Guilherme Marinoni. Antecipação de tutela. 9. ed. São Paulo: Revista dos Tribunais, 2006.

MATTOS, Patrícia Castro. As visões de Weber e Habermas sobre direito e política. Porto alegre: Sergio Antonio fabris, 2002.

MEDINA, José Miguel Garcia. Novo código de processo civil comentado: com remissões e notas comparativas ao CPC/1973. 4. ed. São Paulo: Revista dos Tribunais, 2016.

MELO, Maria Rita de Carvalho. Aspectos atuais da tutela antecipada. São Paulo: Verbatim, 2010.

MITIDIERO, Daniel. Colaboração no processo civil: pressupostos sociais, lógicos e éticos. 2. ed. São Paulo: RT, 2011.

MÓL, Ana Lucia Ribeiro. Antecipação de tutela: sem a prévia oitiva do réu no estado democrático de direito. Montes Claros: Unimontes, 2012.

NEVES, Daniel Amorim Assumpção. Manual de direito processual civil. 8. ed. Bahia: Jus Podivm, 2016.

PEREIRA, Rodrigo da Cunha. Direito e psicanalise: a subjetividade na objetividade dos atos e fatos jurídicos. In: GALUPPO, Marcelo Campos. O Brasil que queremos: reflexões sobre o estado democrático de direito. Belo Horizonte: PUC Minas, 2006.

SIEBENEICHLER, Flávio Beno. Jurgen Habermas: razão comunicativa e emancipação. 3. ed. Rio de Janeiro: Tempo Brasileiro, 1994.

THEODORO JÚNIOR, Humberto. Curso de direito processual civil. 57. ed. Rio de Janeiro: Forense, 2016.

TUCCI, José Rogério Cruz e. Garantias constitucionais do processo civil. São Paulo: Revista dos Tribunais, 1999.

VELOSO, Cynara Silde Mesuita Veloso. Súmulas vinculantes no Estado democrático de direito. Revista da Ordem dos Advogados do Brasil, v. 35, n. 80, p. 41-52, jan.jun. 2005. VELOSO, Cynara Silde Mesquita. Súmulas vinculantes como entraves ideológicos ao processo jurídico de enunciação de uma sociedade democrática. 2008. 389 f. Tese (Doutorado em Direito) - Pontifícia Universidade Católica de Minas Gerais, Belo Horizonte, 2008. 
WAMBIER, Teresa Arruda Alvim. Da liberdade do juiz na concessão de liminares e a tutela antecipatória. In: WAMBIER, Teresa Arruda Alvim. Aspectos polêmicos da antecipação de tutela. São Paulo: Revista dos Tribunais, 1997.

ZAVASCKI, Teori Albino. Antecipação de tutela. São Paulo: Saraiva, 2009.

1 FAZZALARI, Elio. Instituições de direito processual. Tradução Elaine Nassif. Campinas: Bookseller, 2006.

2 BRASIL. Lei no . 13.105, de 16 de março de 2015. Código de Processo Civil. Presidência da República, Brasília, DF. Disponível em: <http://www.planalto.gov.br/ccivil_03/_ato2015-2018/2015/lei/L13105.htm>. Acesso em: 19 jan. 2017.

3 Afinal, a liminar da ação possessória, mantida no Novo Código de Processo Civil, continua a ser espécie de tutela de evidência, bem como a concessão do mandado monitório e da liminar nos embargos de terceiros, e nenhuma delas está prevista no art. 311 do Novo CPC. A única conclusão possível é que o rol de tal dispositivo legal é exemplificativo. (NEVES, Daniel Amorim Assumpção. Manual de direito processual civil. 8. ed. Bahia: Jus Podivm, 2016. p. 484-485).

4 BUENO, Cassio Scarpinella. Tutela antecipada. São Paulo: Saraiva, 2004.

5 CARMIGNANI, Maria Cristina da Silva. A origem romana da tutela antecipada. São Paulo: LTR, 2000. p. 23.

6 ZAVASCKI, Teori Albino. Antecipação de tutela. São Paulo: Saraiva, 2009.

7 LOPES, João Batista. Tutela antecipada no processo civil brasileiro. 4. ed. São Paulo: Saraiva, 2009. p. 40.

8 Lei n ${ }^{\circ}$. 13.105, de 16 de março de 2015. Código de Processo Civil. Presidência da República, Braślia, DF. Disponível em: <http://www.planalto.gov.br/ccivil_03/_ato2015-2018/2015/lei/L13105.htm>. Acesso em: 19 jan. 2017.

9 BRASIL. Lei n ${ }^{\circ}$ 5.869, 11 de janeiro de 1973. Revogado pela Lei n. 13.105 de março de 2015. Institui o Código de Processo Civil. Presidência da República, Brasília, DF. Disponível em: <http://www.planalto.gov.br/ccivil_03/ leis/L5869.htm >. Acesso em: 19 jan. 2017.

10 FAZZALARI, Elio. Instituições de direito processual. Tradução Elaine Nassif. Campinas: Bookseller, 2006.

11 BRASIL. Lei ${ }^{\circ}{ }^{\text {5.8.869, } 11}$ de janeiro de 1973. Revogado pela Lei n. 13.105 de março de 2015. Institui o Código de Processo Civil. Presidência da República, Brasília, DF. Disponível em: <http://www.planalto.gov.br/ccivil_03/ leis/L5869.htm >. Acesso em: 19 jan. 2017.

12 BRASIL. Lei no ${ }^{\circ}$ 13.105, de 16 de março de 2015. Código de Processo Civil. Presidência da República, Brasília, DF. Disponível em: < http://www.planalto.gov.br/ccivil_03/_ato2015-2018/2015/lei/L13105.htm>. Acesso em: 19 jan. 2017.

13 MELO, Maria Rita de Carvalho. Aspectos atuais da tutela antecipada. São Paulo: Verbatim, 2010.

14 Ibidem, p. 36.

15 LEAL, Rosemiro Pereira. Teoria geral do processo: primeiros estudos. 12. ed. Rio de Janeiro: Forense, 2014. p. 158.

16 MÓL, Ana Lucia Ribeiro. Antecipação de tutela: sem a prévia oitiva do réu no estado democrático de direito. Montes Claros: Unimontes, 2012.

17 CARMIGNANI, Maria Cristina da Silva. A origem romana da tutela antecipada. São Paulo: LTR, 2000.

18 HABERMAS, Jürgen. Direito e democracia: entre facticidade e validade. 2. ed. Tradução Flávio Beno Siebeneichler. Rio de Janeiro: Tempo Brasileiro, 2003. v. 1.

19 BRASIL. Lei nº. 13.105, de 16 de março de 2015. Código de Processo Civil. Presidência da República, Brasília, DF. Disponível em: < http://www.planalto.gov.br/ccivil_03/_ato2015-2018/2015/lei/L13105.htm > . Acesso em: 19 jan. 2017.

20 THEODORO JÚNIOR, Humberto. Curso de direito processual civil. 57. ed. Rio de Janeiro: Forense, 2016.

21 BRASIL. Lei no. 13.105, de 16 de março de 2015. Código de Processo Civil. Presidência da República, Brasília, DF. Disponível em: <http://www.planalto.gov.br/ccivil_03/_ato2015-2018/2015/lei/L13105.htm>. Acesso em: 19 jan. 2017.

22 BRASIL. Lei n ${ }^{\circ}$ 5.869, 11 de janeiro de 1973. Revogado pela Lei n. 13.105 de março de 2015. Institui o Código de Processo Civil. Presidência da República, Brasília, DF. Disponível em: <http://www.planalto.gov.br/ccivil_03/ leis/L5869.htm >. Acesso em: 19 jan. 2017.

23 BRASIL. Lei no ${ }^{\circ}$ 13.105, de 16 de março de 2015. Código de Processo Civil. Presidência da República, Brasília, DF. Disponível em: <http://www.planalto.gov.br/ccivil_03/_ato2015-2018/2015/lei/L13105.htm>. 
Acesso em: 19 jan. 2017.

24 BRASIL. Lei $\mathrm{n}^{\circ}$ 5.869, 11 de janeiro de 1973. Revogado pela Lei n. 13.105 de março de 2015. Institui o Código de Processo Civil. Presidência da República, Brasília, DF. Disponível em: <http://www.planalto.gov. br/ccivil_03/leis/L5869.htm >. Acesso em: 19 jan. 2017.

25 BUENO, Cassio Scarpinella. Manual de direito processual civil. 2. ed. São Paulo: Saraiva, 2016.

26 BRASIL. Lei no . 13.105, de 16 de março de 2015. Código de Processo Civil. Presidência da República, Brasília, DF. Disponível em: <http://www.planalto.gov.br/ccivil_03/_ato2015-2018/2015/lei/L13105.htm>. Acesso em: 19 jan. 2017.

27 BUENO, Cassio Scarpinella. Manual de direito processual civil. 2. ed. São Paulo: Saraiva, 2016.

28 NEVES, Daniel Amorim Assumpção. Manual de direito processual civil. 8. ed. Bahia: Jus Podivm, 2016. p. 411.

29 BRASIL. Lei $n^{\circ} .13 .105$, de 16 de março de 2015. Código de Processo Civil. Presidência da República, Brasília, DF. Disponível em: <http://www.planalto.gov.br/ccivil_03/_ato2015-2018/2015/lei/L13105.htm>. Acesso em: 19 jan. 2017.

30 NEVES, Daniel Amorim Assumpção. Manual de direito processual civil. 8. ed. Bahia: Jus Podivm, 2016. p. 413, acréscimo nosso.

31 NEVES, loc. cit.

32 BRASIL. Lei $\mathrm{n}^{\circ} .13 .105$, de 16 de março de 2015. Código de Processo Civil. Presidência da República, Brasília, DF. Disponível em: <http://www.planalto.gov.br/ccivil_03/_ato2015-2018/2015/lei/L13105.htm>. Acesso em: 19 jan. 2017.

33 Ibidem.

34 Ibidem.

35 BRASIL. Lei no 8.952, de 13 de dezembro de 1994. Altera dispositivos do código de processo civil sobre o processo de conhecimento e o processo cautelar. Presidência da República, Brasília, DF. Disponível em: <http://www. planalto.gov.br/ccivil_03/leis/L8952.htm>. Acesso em: 26 jan. 2017.

36 MEDINA, José Miguel Garcia. Novo código de processo civil comentado: com remissões e notas comparativas ao CPC/1973. 4. ed. São Paulo: Revista dos Tribunais, 2016. p. 480.

37 BUENO, Cassio Scarpinella. Manual de direito processual civil. 2. ed. São Paulo: Saraiva, 2016.

38 Lei nº. 13.105, de 16 de março de 2015. Código de Processo Civil. Presidência da República, Brasília, DF. Disponível em: < http://www.planalto.gov.br/ccivil_03/_ato2015-2018/2015/lei/L13105.htm>. Acesso em: 19 jan. 2017.

39 Ibidem.

40 NEVES, Daniel Amorim Assumpção. Manual de direito processual civil. 8. ed. Bahia: Jus Podivm, 2016.

41 MATTOS, Patrícia Castro. As visões de Weber e Habermas sobre direito e política. Porto alegre: Sergio Antonio fabris, 2002.

42 LEAL, Rosemiro Pereira. Teoria processual da decisão jurídica. São Paulo: Landy, 2002.

43 LEAL, Rosemiro Pereira. Teoria geral do processo. 6. ed. São Paulo: IOB Thomson, 2005. p. 98.

44 VELOSO, Cynara Silde Mesuita Veloso. Súmulas vinculantes no Estado democrático de direito. Revista da Ordem dos Advogados do Brasil, v. 35, n. 80, p. 41-52, jan./jun. 2005.

45 LEAL, Rosemiro Pereira. Teoria geral do processo. 6. ed. São Paulo: IOB Thomson, 2005. p. 96.

46 LEAL, Rosemiro Pereira. Teoria geral do processo. 6. ed. São Paulo: IOB Thomson, 2005. p. 96.

47 LEAL, Rosemiro Pereira. Teoria geral do processo. 6. ed. São Paulo: IOB Thomson, 2005. p. 97-98.

48 BRASIL. Lei ${ }^{\circ}{ }^{5}$ 5.869, 11 de janeiro de 1973. Revogado pela Lei n. 13.105 de março de 2015. Institui o Código de Processo Civil. Presidência da República, Brasília, DF. Disponível em: <http://www.planalto.gov. br/ccivil_03/leis/L5869.htm>. Acesso em: 19 jan. 2017.

49 FERES, Carlos Roberto. Antecipação da tutela jurisdicional. São Paulo: Saraiva, 1999. p. 18.

50 FERES, loc. cit.

51 BUENO, 2004, op. cit., p. 13, acréscimo nosso.

52 Ibidem.

53 LOPES, João Batista. Tutela antecipada no processo civil brasileiro. 4. ed. São Paulo: Saraiva, 2009.

54 MEDINA, José Miguel Garcia. Novo código de processo civil comentado: com remissões e notas comparativas 
ao CPC/1973. 4. ed. São Paulo: Revista dos Tribunais, 2016.

5 LOPES, João Batista. Tutela antecipada no processo civil brasileiro. 4. ed. São Paulo: Saraiva, 2009.

56 WAMBIER, Teresa Arruda Alvim. Da liberdade do juiz na concessão de liminares e a tutela antecipatória. In: WAMBIER, Teresa Arruda Alvim. Aspectos polêmicos da antecipação de tutela. São Paulo: Revista dos Tribunais, 1997.

57 BUENO, Cassio Scarpinella. Tutela antecipada. São Paulo: Saraiva, 2004. p. 8.

58 FERES, Carlos Roberto. Antecipação da tutela jurisdicional. São Paulo: Saraiva, 1999. p. 19.

59 BUENO, loc. cit.

60 MÓL, Ana Lucia Ribeiro. Antecipação de tutela: sem a prévia oitiva do réu no estado democrático de direito. Montes Claros: Unimontes, 2012.

61 VELOSO, Cynara Silde Mesquita. Súmulas vinculantes como entraves ideológicos ao processo jurídico de enunciação de uma sociedade democrática. 2008. 389 f. Tese (Doutorado em Direito) - Pontifícia Universidade Católica de Minas Gerais, Belo Horizonte, 2008.

62 Ibidem, p. 321-322.

63 Ibidem, p. 159.

64 LEAL, Rosemiro Pereira. Teoria geral do processo: primeiros estudos. 12. ed. Rio de Janeiro: Forense, 2014.

65 Ibidem.

66 Ibidem.

67 Ibidem.

68 Ibidem

69 Ibidem.

70 Ibidem

71 Ibidem, p. 159.

72 Ibidem.

73 Ibidem.

74 BRASIL. Constituição (1988). Emenda constitucional no 91, de 2016. Presidência da República, Brasília, DF. Disponível em: <http://www.planalto.gov.br/ccivil 03/constituicao/constituicao.htm>. Acesso em: 20 jan. 2017.

75 Ibidem.

76 DALLARI, Dalmo de Abreu. O poder dos juízes. São Paulo: Saraiva, 1996.

77 LEAL, Rosemiro Pereira. Teoria geral do processo: primeiros estudos. 12. ed. Rio de Janeiro: Forense, 2014.

78 Ibidem.

79 TUCCI, José Rogério Cruz e. Garantias constitucionais do processo civil. São Paulo: Revista dos Tribunais, 1999.

80 Ibidem.

81 GALUPPO, Marcelo Campos. Igualdade e diferença: estado de democrático de a partir do pensamento de Habermas. Belo Horizonte: Mandamentos, 2002.

82 Ibidem.

83 LEAL, 2014, op. cit., p. 97.

84 Ibidem.

85 Ibidem, p. 99. (grifo do autor).

86 BRASIL. Lei nº. 13.105, de 16 de março de 2015. Código de Processo Civil. Presidência da República, Brasília, DF. Disponível em: <http://www.planalto.gov.br/ccivil_03/_ato2015-2018/2015/lei/L13105.htm>. Acesso em: 19 jan. 2017.

87 BRASIL. Lei ${ }^{\circ}$ 5.869, 11 de janeiro de 1973. Revogado pela Lei n. 13.105 de março de 2015. Institui o Código de Processo Civil. Presidência da República, Brasília, DF. Disponível em: <http://www.planalto.gov. br/ccivil 03/leis/L5869.htm>. Acesso em: 19 jan. 2017.

88 BRASIL. Lei no ${ }^{\circ}$ 13.105, de 16 de março de 2015. Código de Processo Civil. Presidência da República, Brasília, DF. Disponível em: <http://www.planalto.gov.br/ccivil_03/_ato2015-2018/2015/lei/L13105.htm>. Acesso em: 19 jan. 2017.

89 Ibidem.

90 MADEIRA, Dhenis Cruz et al. Processo, jurisdição e ação em James Goldschmidt. In: LEAL, Rosemiro Pereira. Estudos continuados de teoria do processo: a pesquisa jurídica no curso de mestrado em direito processual. Porto Alegre: Síntese, 2005. v. 6.

91 Ibidem, p. 74. 
92 ALMEIDA, Andréa Alves de. Processualidade jurídica e legitimidade normativa. Belo Horizonte: Fórum, 2005.

93 Ibidem, p. 123-123.

94 Ibidem.

95 LEAL, Rosemiro Pereira. Teoria processual da decisão jurídica. São Paulo: Landy, 2002.

96 Ibidem, p. 75.

97 TUCCI, José Rogério Cruz e. Garantias constitucionais do processo civil. São Paulo: Revista dos Tribunais, 1999.

98 TUCCI, José Rogério Cruz e. Garantias constitucionais do processo civil. São Paulo: Revista dos Tribunais, 1999. p. 102.

99 LEAL, Rosemiro Pereira. Teoria geral do processo: primeiros estudos. 12. ed. Rio de Janeiro: Forense, 2014.

100 Ibidem, p. 99

101 TUCCI, José Rogério Cruz e. Garantias constitucionais do processo civil. São Paulo: Revista dos Tribunais, 1999.

102 Ibidem. p. 108.

103 CINTRA, Antonio Carlos de Araújo; GRINOVER, Ada Pellegrini; DINAMARCO, Cândido Rangel. Teoria geral do processo. 28. ed. São Paulo: Malheiros, 2013.

104 BRASIL. Constituição (1988). Emenda constitucional no 91, de 2016. Presidência da República, Brasília, DF. Disponível em: <http://www.planalto.gov.br/ccivil_03/constituicao/

constituicao.htm>. Acesso em: 20 jan. 2017.

105 Ibidem.

106 BRASIL. Lei no ${ }^{\circ}$ 13.105, de 16 de março de 2015. Código de Processo Civil. Presidência da República, Brasília, DF. Disponível em: <http://www.planalto.gov.br/ccivil_03/_ato2015-2018/2015/lei/L13105.htm>. Acesso em: 19 jan. 2017.

107 CINTRA, Antonio Carlos de Araújo; GRINOVER, Ada Pellegrini; DINAMARCO, Cândido Rangel. Teoria geral do processo. 28. ed. São Paulo: Malheiros, 2013.

108 Ibidem.

109 MITIDIERO, Daniel. Colaboração no processo civil: pressupostos sociais, lógicos e éticos. 2. ed. São Paulo: RT, 2011.

110 PEREIRA, Rodrigo da Cunha. Direito e psicanalise: a subjetividade na objetividade dos atos e fatos jurídicos. In: GALUPPO, Marcelo Campos. O Brasil que queremos: reflexões sobre o estado democrático de direito. Belo Horizonte: PUC Minas, 2006. p. 16.

111 LEAL, Rosemiro Pereira. Teoria geral do processo: primeiros estudos. 12. ed. Rio de Janeiro: Forense, 2014. p. 10. (grifo do autor).

112 Ibidem.

113 LEAL, Rosemiro Pereira. Teoria geral do processo: primeiros estudos. 12. ed. Rio de Janeiro: Forense, 2014.

114 BRASIL. Constituição (1988). Emenda constitucional no 91, de 2016. Presidência da República, Brasília, DF. Disponível em: <http://www.planalto.gov.br/ccivil_03/constituicao/constituicao.htm>. Acesso em: 20 jan. 2017.

115 LEAL, Rosemiro Pereira. Teoria processual da decisão jurídica. São Paulo: Landy, 2002. p. 171.

116 MARINONI, Luiz Guilherme Marinoni. Antecipação de tutela. 9. ed. São Paulo: Revista dos Tribunais, 2006. p. 27.

117 Ibidem.

118 BRASIL. Constituição (1988). Emenda constitucional no 91, de 2016. Presidência da República, Brasília, DF. Disponível em: <http://www.planalto.gov.br/ccivil_03/constituicao/constituicao.htm>. Acesso em: 20 jan. 2017.

119 TUCCI, José Rogério Cruz e. Garantias constitucionais do processo civil. São Paulo: Revista dos Tribunais, 1999. p. 102-103. 


\title{
(IN) COMPATIBILITY OF URGENT PROVISIONAL RELIEF IN THE 2015 CPC WITH THE DEMOCRATIC STATE OF LAW
}

\begin{abstract}
The objective of this article was to analyze the institute of urgent provisional relief in the new Brazilian Code of Civil Procedure (NCPC), of 2015, focusing on the neoinstitutionalist theory of the process. From this theoretical matrix, one wonders: is the urgent provisional relief, as established in the NCPC, in consonance with the democratic State of law? In order to answer such question, the methodological path of the research is qualitative and its objectives are to be exploratory. Regarding the technical procedures adopted in the analysis, the research is bibliographical and documentary, since a theoretical reference will be used through doctrine and the relevant legislation. The results of the investigation led us to consider that, although the relevant institute is important, there is an incongruity regarding equal access to justice, from the perspective of the litigants. Thus, one can perceive the impossibility of exercising the principles of adversary system and full defense for the respondents, in consonance with the principle of equality, understood on the basis of reciprocity. This restriction refers to the impossibility of the respondent's participation in the preliminary stage of the proceedings, since when the provisional relief is granted in advance, according to the current model, the respondent is subject to a decision without having previously participated in the procedural debate and contributed to the result of the decision, thus disrespecting the principle of cooperation and the adversarial system, aligned with the power of influence pertaining to the rights of the parties. Therefore, the study also considered that way in which urgent provisional relief is standardized, although an alternative to "the plaintiff who is right" - in the words of Marinoni, it is not reasonable, within the perspective of due process of law. In view of this, it can be concluded that the proceedings for urgent provisional relief must be improved and, as such, include a mandatory prior hearing for justification in the initial phase of the process, in which the principles of the adversarial system, full defense and isonomy will be respected.
\end{abstract}

Keywords: Urgent provisional relief. Neoinstitutionalist theory of the process. Adversary system. Isonomy. Full defense.

Submetido: 9 fev. 2017

Aprovado: 6 jun. 2017

R. Opin. Jur., Fortaleza, ano 15, n. 20, p.112-137, jan./jun. 2017 